\title{
A Review of Research Literature on Obstacles that Prevent Use of ICT in Pre-Service Teachers' Educational Courses
}

\author{
Hassan Mirzajani (Corresponding author) \\ Faculty of Educational Studies, Universiti Putra Malaysia, 43400 UPM, Serdang, Selengor, Malaysia \\ E-mail:mirzajanihassan@yahoo.com \\ Rosnaini Mahmud \\ Faculty of Educational Studies, Universiti Putra Malaysia, 43400 UPM, Serdang, Selengor, Malaysia \\ E-mail: ros@educ.upm.edu.my \\ Ahmad Fauzi Mohd Ayub \\ Faculty of Educational Studies, Universiti Putra Malaysia, 43400 UPM, Serdang, Selengor, Malaysia \\ E-mail: afauzi@educ.upm.edu.my \\ Wong Su Luan \\ Faculty of Educational Studies, Universiti Putra Malaysia, 43400 UPM, Serdang, Selengor, Malaysia \\ E-mail: suluan@upm.edu.my
}

Received: 08-02- 2015

Accepted: 28-03-2015

Published: 30-04-2015

doi:10.7575/aiac.ijels.v.3n.2p.25

URL: http://dx.doi.org/10.7575/aiac.ijels.v.3n.2p.25

\begin{abstract}
In spite of growing amount of technologies, tools and information communication and technology (ICT) by providing pre-service teacher education courses, pre-service teachers' ICT utilization is not still as predicted. Research shows many barriers influencing pre-service teachers' utilization of ICT. Many researchers have identified a number of factors to describe why student teachers do not feel ready to use ICT in their classrooms. The purpose of this review of research literature is to discover what reasons are key obstacles that prevent utilization of ICT in pre-service teachers' educational courses. The review results show that most of the researchers believe that lack of enough training, lack of suitable software and hardware, lack of knowledge and skills, lack of ICT leadership support, lacking time, and lack of self-efficacy are the key barriers for utilization of ICTs in pre-service teachers' educational courses. The study also concluded that understanding the amount to which these obstacles affect ICT users and institutes can support decisionmaking on how to equip them.
\end{abstract}

Keywords: pre-service teacher, ICT utilization, obstacles, educational courses

\section{Introduction}

In the early 1980s, Information Communication and Technology (ICT) was introduced as an invention that could be used in schools. It was speculated that this new trend would change the face of education with high impacts on teaching and learning. Furthermore, ICT could increase the quality of education by helping teachers perform their duties in line with enhanced efficiency of students' learning. (Chai, \& Tsai, 2010; Hong\& Songan, 2011; Goktas \& Yildirim, 2009). Whereby, many governments took ICT investment into account by providing schools with ICT and equipment. Despite enormous investment of financial and human resources, future teacher training programmes do not now provide pre-service teachers with the essential knowledge, skills and abilities, and practices to organize them to use ICTs efficiently in their future occupation. (Goktas \& Yildirim, 2009; Mehlinger \& Powers, 2002; Bullock, 2004; Moursund $\&$ Bielefeldt, 1999).In other words, despite important political will and investing by countries on technical tools and training, levels of ICT utilization in universities for teaching and learning are often low. According to Ottesen( 2006) use of ICTs for encouraging learning, is necessary to prepare students with the skills to contribute and success in an information society, need to make skills and remove the obstacles. ICT at institutions of higher education is often poorly carry out and is based on unconfirmed optimism. A large number of pre-service teachers are still irresolute or disinclined to use of ICT for teaching and learning tasks (Said Al-Senaidi, 2009). Investigation has revealed major hindrances in full integration of ICT into the learning and teaching practice in teacher training institutes. Furthermore, there are not common solutions to the difficulties as the ICT acceptance is not solely a technological problem. In its place, the speed of acceptance is impacted by elements which are sociological, economic psychological and organizational (Said Al-Senaidi, 2009).As mentioned above, using ICTs in pre-service teacher training is affected by several obstacles. Hence, the purpose of this research is to explore which main obstacles are universally encountered and which reasons are the most useful for current ICT utilization in student teacher training programs. 


\section{Obstacles in to Use ICT}

Numerous researchers have classified obstacles into two categories: the external and internal obstacles. The external obstacles include: lack of operational education and technological difficulties, and technical problem, lack of enough time, inadequate technical support, and incomplete resources or lack of contact to quality multiplying resources. Internal obstacles relate to the educators' approaches to use ICT such as resistance to change, lack of self-confidence, teachers' negative attitudes, and lack of awareness about advantage of using ICT (Said Al-Senaidi, 2009; Snoeyink \& Ertmer, 2001). Comprehending the scope of what these obstacles have an effect on pre-service teachers and organizations be able to support decide how they are to be engaged (Becta, 2004). A review of relevant literature and research studies (Dogra \& Thakur 2013; Goktas, Yildirim, \& Yildirim, 2009; Gülbahar ,2008; Arouri 2013;Brush, Glazewski, \& Hew, 2008; Woldab,2014; Türkmen,Pedersen, \& McCarty, 2007; Liu, 2012; Yuen Fook, et al.,(2011); Luan \& Teo (2009); Baleghi-Zadeh,et al.(2014) of ICT utilization revealed that use of ICT among pre-service teachers was low. Many of these researchers have also attempted to identify the obstacles to the use of technology. Several researches examined the obstacles to use ICT among pre-service teachers. From these studies and other similar studies, the barriers may be collected into several categories that include :( a) Resource-related obstacles (b) Institutional obstacles, and (c) Attitudinal obstacles (Table.1).

Table 1. The obstacles to the use of technology

\begin{tabular}{lll}
\hline Resource-related obstacles & Institutional obstacles & Attitudinal obstacles \\
\hline - Availability of resources & $\bullet$ Inadequate Financial Resources & $\bullet$ Fear of going wrong \\
•Lack of sufficient education & $\bullet$ Lack Of Enough Time & $\bullet$ Users resistance to change and \\
- Lack of knowledge and skills & $\bullet$ Lack Of Rewards Or Incentives & negative attitudes \\
- Lack of leadership & $\bullet$ Lack Of Commitment & $\bullet$ Pre-service teachers self-efficacy \\
& & $\bullet$ Attitudes \\
\hline
\end{tabular}

\subsection{Resource-related obstacles}

Resource-related obstacles include lack of ICT equipment and tools, complexity of hardware and software, lack of suitable software and tools, lack of elementary skills, knowledge of ICT, the rapid pace of technological change, lack of technical support, and shortage of high-quality software.

\subsubsection{Adequate Resources}

This mentions the suitable and sufficient ICT tools to be available to the users. Technological resources are the tools that are essential to make implementation work--the hardware, software, audio-visual media, etc (Ely 1999). This factor relates to the universal structure of the institute and how well that organization can back the users. This means that the institutes essentially make available the necessary tools to backing the use of ICT in teaching and learning process. Therefore, if those pieces of equipment are inaccessible, the achievement of those learning objectives will be significantly hindered. Those involved in educational change must work to ensure that necessary resources are both generally available and equally available to each student and teacher (Ellsworth, 2000). Dogra and Thakur (2013) investigated on availability and utilization of ICT resources in pre- service teacher training course in Delhi. The major finding of this study indicated that many teacher education institutes undertaken in the study were lacking adequate ICT tools for the pre-service teachers. The range of the ICT resources has not been very encouraging as the future teachers were exposed to only few of them, and the utilization of the ICT tools has been dismal. Arouri (2013) investigated Jordanian pre-service teachers' experiences with ICT access. This research exposed that Jordanian student teachers had a limited access to ICT tools in their public schools and before enrolling at the university. In another study Goktas, Yildirim and Yildirim (2009) carried out study on the key obstacles and potential enablers for integrating ICT in Turkey's student teacher training programs. The results directed that most of the participants mentioned (a) lack of hardware, (b) lack of materials and appropriate software and (c) lack of in-service training as the key obstacles for utilization of ICTs in student teacher training programs. Hence, an invention without resources like tools, materials, and money to support its employment will not be effective. Dogra and Thakur (2013) emphasized change causes obtaining the necessary resources for ICT utilization. Other investigators who have acknowledged resources as a significant part of ICT implementation include Espino (2012), Arouri (2013), Brush, Glazewski, and Hew (2008), Hutchison (2009), Qablan, Abuloum and Al-Ruz (2009), Dawson(2008), Brush, and Saye (2009), Bingimlas (2009), Goktas, Yildirim and Yildirim (2009), Obiri-Yeboah, Kwarteng, and Kyere-Djan (2013), Al-Senaidi and Poirot (2009), Gülbahar (2008), and Gill and Dalgarno (2008).t

\subsubsection{Lack of Adequate Training}

Lacking adequate training to use technology or ICT, the invention will stop to exist. Pre-service preparation can support them to defeat obstacles, yet numerous researchers discuss that it often failure to do this. Despite the fact that absence of pre-service teachers training is main obstacle (Goktas, Yildirim, \& Yildirim 2009; Bingimlas (2009). Undoubted, insufficient training of user to use ICT is one of the most common causes of non-adoption or discontinuance is insufficient training of user to use ICT (Ellsworth, 2000). Studies reveled that there are frailty in the strategy and distribution of numerous courses. Initial pre-service teacher's education obtains specific consideration in the research. Luan \& Teo (2009) Investigated on the technology acceptance among student teachers in Malaysia. Finding in this study revealed that, Malaysian student teachers do not use computer technology to its fullest potential. Due to, lack of 
ICT training or ineffective training sessions afforded. Furthermore, inside institutes offering pre-service teacher training, access to ICT may be difficult, but perhaps more important obstacle lies in the fact that pre-service teachers do not have experience of using ICT to deliver the course. As a result of this, lack of training models of utilization ICT, indicated to a difference between pre-service teachers presumption of use of technology and their actual use of ICT (Whetstone \& Carr-Chellman 2001). Certainly pre-service teachers' training is an essential part of most effective an innovations (Goktas, et.al 2009).

\subsubsection{Lack of Knowledge and Skills}

According to Ely (1999), "the people who will ultimately implement any innovation must possess sufficient knowledge and skills to do the job" (p. 4). Pre-service teachers who will be using an innovation must have enough knowledge, skills and technical knowledge to be able to influence change. Knowledge and skills are those essentials by the critical user of the invention. Lacking them, pre-service teachers come to be disappointed and disabled (Surry \& Ely, 2002). Alkhawaldeh (2010) recognize ICT training as key part of the innovation implementation. ICT Knowledge and skills is important as it is a pre-requisite for networking of e-library services and resource sharing. Furthermore, Knowledge and skills are essential to mention that it not only express the intentional users' present level but also users' judgment in being able to improve the required skills to effectively use the invention. According to Rogers (2003), the "complexity" of the invention will influence ICT usage in that it will necessitate more preparation or skill improvement by the users. Thus, it is essential that training courses or workshops be carried out to help pre-service teachers realize the advantage or value of using the technological innovation as well as learn the relevant skills to ICT utilization. Brush, Glazewski and Hew (2008) contend that knowledge and skill affect useing ICT and has implications for pre-service teacher ICT utilization. Other investigators have connected training or knowledge and skills to effective ICT implementation (Haber \& Mills2008; Bingimlas, 2009; Espino, 2012; Teo, 2009; Anderson \& Maninger, 2007;, Dogra \& Thakur, 2013; Arouri, 2013; Henning, Robinson, Herring \& McDonald 2006; Salentiny, 2012; Hutchison, 2009; Mutohar, 2012; Liu, 2012).

\subsubsection{Lack of Leadership}

Researchers identify leadership as an active participation of the management in the procedure of invention acceptance and utilization. Ely (1999) express that leadership includes prepared backing and hearten the ICT users. Woldab (2014) indicated that administrators' necessity actively backed the change and connected their support to users. Assistance of the technology by superintendents is usually mentioned as a critical portion of the education change procedure. According to Surry and Ely (2002), leadership of the administrative agent of the organizational structure, and leadership within the institute are associated to the everyday actions of the invention existence implemented. It is mentioned as the level of possession and backing given by the principal who will administer the daily activities of those using the invention. The eagerness of these administrators directly affect the incentive of the users of the technology. Administrators should provide backing and persuasion, answer the questions, reduce anxieties, and work as position models (Ely, 1999, 1990). Many studies have indicated significant of leadership support (Goktas, et al. 2009; Ertmer et al., 2006; Espino, 2012; Dogra \& Thakur, 2013; Gülbahar, 2008; Mutohar, 2012; Brush, Glazewski, \& Hew, 2008; Dawson, 2008; Bingimlas, 2009; Ertmer \& Ottenbreit-Leftwich, 2010; Türkmen, et al., 2007).

\subsection{Institutional Obstacles}

Institutional obstacles include obstacles such as inadequate financial resources for institutions to invest in technology, lack of incentives, rewards and encourage for future teacher's improvement for using ICT, insufficient time given for lecture to learn to use technology, and lack of appropriate commitment.

\subsubsection{Time}

Time is used to learn new innovation skills or procedures for innovation use. Availability of time refers to an emotive disquiet causing from the use of existing courses or equipment that are observed as incompetent, ineffectual (Ely, 1999, 1990). Undoubtedly, time is an important factor for the acceptance of an invention .Moreover, it is a long procedure that requires disseminating at a good time. Alkhawaldeh (2010) indicated possibility to exercise or use the invention as serious to implementation of an innovation. Insufficient or lacking time is predictable as an obstacle to utilization of ICT in higher education. Furthermore, Ely indicated that time is essential to confirm that users recognize the invention and improve the capabilities to accept the technology. It also mentions the users' inclination to allocate time to learn new knowledge for ICT implementation (Ely, 1999, 1990a). Many researchers have emphasized time as an important part of ICT utilization (Dogra \& Thakur, 2013; Haber \& Mills, 2008; Obiri-Yeboah et al., 2013; Al-Senaidi, \& Poirot, 2009; Ertmer et al., 2006; Brush, Glazewski, \& Hew 2008; Henning et al., 2006; Salentiny, 2012; Bingimlas, 2009; Hutchison, 2009; Gill, \& Dalgarno, 2008; Türkmen et al., 2007; Slaouti \& Barton, 2007; Gülbahar, 2008).

\subsubsection{Rewards or Incentives}

It is usual that persons need to be invigorated, distinguished and acknowledged for their performance or usage of the invention. They require to be persuaded in their performance of invention or use of the technology. Intrinsic or extrinsic motivation or incentives can enhance some value of the invention; therefore, it can develop ICT utilization. Incentives and rewards motivate innovation users. These can be either intrinsic or extrinsic. Reward and incentives vary from user to user (Ely 1999, 1990). External incentives are delivered to proposed users as a means to encourage them to engage the invention. Rogers (2003) record numerous types of rewards and talks over the role that societal monitoring plays in the ICT utilization procedure. Arouri (2013) identified rewards as a significant factor to access ICT and its usage. Ely (1999) mentioned rewards sometimes that helps as a supposition of incentives or fear of penalty. Ely states that it attends as an incentive to change a user to action. Moreover, he revealed that incentives and rewards were of fewer 
influence than other situation. However, it can be considered that incentives may be offered to encourage adopters to implement an invention. Haber and Mills (2008) argue for the use of incentives as portion of ethical support in the course of ICT implementation.

\subsubsection{Commitment}

Implantation of an innovation takes time and requires many actions. Users of ICT should be prepared to presume the pliability of accepting new inventions. This acknowledges that "an unqualified go-ahead and vocal support for innovation by key players and other stakeholders is necessary" for successful change (Ely, 1990a, p301).This situation is more usually indicated by the initial principal of the organization, like an administrator. He cited that responsibility is evaluated by the realization of ICT users. Nawawi et.al (2005) perceived the necessity of observable backing for invention from top administration of the institute, like leaders and heads of department to accelerate its adoption capacity. Furthermore, Woldab (2014) indicated that training support initiatives is one of the important factors to successful implementation of the e-learning technology in pre-service teachers training. According to Ely, commitment is related with time, management and resources, and incentives and reward. This condition is closely correlated to management because a first commitment may be derived from a chief administrative officer. This is important in the diffusion process because commitment communicates support (Ely, 1990a). Ever since the technology employment has been taking a vast content of activities and time, ICT users, who are engaged in the ICT utilization, have been required to create obligation to their time and efforts .

\subsection{Attitudinal Obstacles}

Attitudinal obstacles include anxiety of shame in front of classmates, percipience that technology does not improve learning change, percipience of computer as being difficult to use, lack of self-confidence in using technology, and undesirable experiences with using ICT in the past, and Lack of motivation to change.

\subsubsection{Fear of Things Going Wrong}

One of major obstacles is fear for pre-service teachers when using technology. Past research has shown computer anxiety to be present in a sizeable minority of teachers, and has mentioned some of the personal and school-based correlates of this fare. It also includes the concern of ICT tools breaking down during using, or fear that if they use the ICT tools, they do something wrong and cause the destruction of the equipment. Undoubtedly, there are important relations among the obstacles affected by a concern of causing injury to ICT tools, and the obstacle affected by a lack of pre-service teacher self-confidence. Cuban et al. (2001) describe that if the technical problems happen every week, or if there is no enough time, then self-confidence in the equipment's value erodes, then this causes an undesirable influence on the quantity of pre-service teachers' ICT utilization. Numerous pre-service teachers have stated fear over potential technological failing, which force them avoid applying technology. Bradley and Russell (1997) argue that an initial beginning of ICT tools fear is the fear users have about being injurious to software or hardware. This concern is thus a potential to make the educators avoid trying to apply the ICT at all.

\subsubsection{Users Resistance to Change}

Many researchers investigating the obstacles to usage of technology use in institutes recommends that in the teaching occupation usually there is an essential opposition to transformation. Dawes (2000) indicated that the describe approach of instructors towards technology expresses users further around what tools the educator has contact to, what exercise they have had, and what kind of population they are part of, than it does about the readiness of the educator to usage technology. The recommendation here then is that the observed conflict to transformation as an obstacle is really only an indicator of other obstacles to the use of technology. Albaugh (1997) describes that: "teachers are often suspicious of new claims and the implementation of new ideas without proof of effectiveness teachers tend to adopt a new technology when that technology helps them to do what they are currently doing better."

\subsubsection{Self-Efficacy Beliefs}

Literature recommends an important relationship among pre-service teachers' self-efficacy and ICT utilization design. Numerous researches have indicated enhanced confidence or self-efficacy for using ICT during training progresses (Willis \& de Montes, 2002; Swain, 2006) and ICT integration procedures courses (Pope et al., 2002). Many investigators have revealed associations among past success with technology, ICT access and technology-related selfefficacy, technology ability, period of ICT use, and utilization of computer among teacher education (Albion, 2001). Confidence symbolizes the users' decision of their abilities to establish and carry out progresses of activity necessary to obtain specified performances (Bandura, 1986). High levels of ICT use within pre-service teachers learning happened when pre-service teachers' self-confidence in using particular innovation was important and their collaborating educators too used those tools in the schools (Pope, Hare, \& Howard, 2005).

\subsubsection{Attitudes}

Pre-service teachers' approaches about using ICT in the classroom can be obstacles in themselves and can be influenced or effected by other obstacles. Fabry and Higgs (1997) separated user attitudes into three categories: perceived importance of technology, self-confidence with technology, and innovation. In spite of the fact that attitudes to some extent depend on user personality, the importance of past ICT usage experience is usually recognized.. Undesirable experiences affect conception of the importance of technology and ease of use, decrease confidence and enhance anxiety. ICT anxiety and fear about change are the main factors to the low level pre-service teachers' use of ICT (Larner \& Timberlake, 1995). Consequences of these concerns are anxiety and fear of shame when pre-service teachers using 
ICT and concern of losing skilled position through a decrease to a lower grade of old methods educational skills(Russell \& Bradley 1997) .

\section{Conclusion}

ICTs utilization in student teachers training courses continues to be critical all around the world. Low level of use of ICT into pre-service teacher training courses is critical issue in high education. In the face of the vast investing of ICT adequate equipment in many countries, student teachers training courses do not presently prepare them with the required skills and knowledge, abilities, and practices to provide pre-service teachers to use ICTs efficiently in their future occupation. According to above- cited researchers, it is observable that utilization of ICTs into pre-service teacher training courses is affected by numerous obstacles. A diversity of activity plans have been established to an efficient utilization of ICTs in pre-service teacher education courses, but numerous obstacles still happen in preparation. To facilitate these activities, obstacles are necessary to be recognized so that they might be solved. The results of this review reveal the key obstacles that prevent the use of ICT by pre-service teachers. These factors can be categorized into resource-related obstacles, institutional obstacles and attitudinal obstacles. Resource-related obstacles include: lack of adequate training, inadequate resources, lack of knowledge and skills and lack of leadership. Institutional obstacles include: inadequate financial resources, lack of enough time lack of rewards or incentives, and lack of commitment. Attitudinal obstacles include: fear of things going wrong, resistance to change and negative attitudes, student teachers self-efficacy beliefs and attitudes. The review showed that most of the researchers believe that lack of adequate training, lack of suitable software and hard ware, lack of knowledge and skills, lack of ICT leadership support, lack of time, and lack of self-efficacy are the key barriers for utilization of ICTs in pre-service teacher education courses. The findings of this study also suggested that understanding the amount to which these obstacles affect ICT users and institutes can support decision-making on how to equip them.

\section{Reference}

Albaugh, P. (1997). The role of skepticism in preparing teachers for the use of technology. 'Education for community': a town and gown discussion panel, Westerville, OH, January 26, 1997.

Albion, P. R. (2001). Some factors in the development of self-efficacy beliefs for computer use among teacher education students. Journal of Technology and Teacher Education, 9(3), 321-347.

Alkhawaldeh , N. (2010). Barriers to Utilizing ICT for Educational Purposes in Jordan. Degree of Master Thesis, Örebro University, Swedish Business School at Örebro University.

Al-Senaidi, S., Lin, L., \& Poirot, J. (2009). Barriers to adopting technology for teaching and learning in Oman. Computers \& Education, 53(3), 575-590.

Arouri , Y., M, S,. (2013). negotiating the Dimensions of the Digital Divide: A Phenomenological Study of Jordanian Pre-service Teachers' Experiences with Information and communication Technology (ICT) Access. Doctoral Dissertation, New Mexico State University.

Baleghi-Zadeh, S., Mohd Ayub, A. F., Mahmud, R., \& Mohd Daud, M. D. (2014). Behavior Intention To Use Of Learning Management System Among Malaysian Pre-Service Teachers: A Confirmatory Factor Analysis. International Journal of Education and Literacy Studies, 2(1), 29-39.

Bandura, A. (1986).Social foundations of thought and action: A social cognitive theory. Englewood Cliffs, NJ: Prentice Hall.

Becta (British Educational Communications and Technology Agency) (June, 2004). A review of the research literature on barriers to the uptake of ICT by teachers. www.becta.org.uk>Retrieved November 1, 2008

Bingimlas, K. A. (2009). Barriers to the successful integration of ICT in teaching and learning environments: A review of the literature. Eurasia Journal of Mathematics, Science \& Technology Education, 5(3), 235-245.

Bradley, G., Russell, G. (1997). Computer experience, school support and computer anxieties. Educational Psychology, 17 (3), pp.267-284.

Brush, T., \& Saye, J. (2009). Strategies for preparing pre-service social studies teachers to effectively integrate technology: Models and practices. Contemporary issues in technology and teacher education, 9(1), 46-59.

Brush, T., Glazewski, K. D., \& Hew, K. F. (2008). Development of an instrument to measure pre-service teachers' technology skills, technology beliefs, and technology barriers. Computers in the Schools, 25(1-2), 112-125.

Bullock, D. (2004). Moving from theory to practice: An examination of the factors that pre-service teachers encounter as they attempt to gain experience teaching with technology during field placement experiences. Journal of Technology and Teacher Education, 12(2), 211-237.

Chai, C. S., Hong, H.-Y., \& Teo, T. K. G. (2009). Singaporean and Taiwanese pre-service teachers' beliefs and their attitude towards ICT use: A comparative study. The Asia-Pacific Education Researcher, 18(1), 117-128.

Cuban, L., Kirkpatrick, H., Peck, C. (2001). High access and low use of technologies in high school classrooms: explaining an apparent paradox. American Educational Research Journal, 38(4), pp. 813 - 834. 
Dawes, L. (2000). The National Grid for Learning and the professional development of teachers: outcomes of an opportunity for dialogue. $\mathrm{PhD}$ thesis.

Dawson, V. (2008). Use of information communication technology by early career science teachers in Western Australia. International Journal of Science Education, 30(2), 203-219.

Dogra, B., S, B., \& Thakur, P. (2013). A Study of Availability and Utilization of ICT Resources in Pre- Service Teacher Education Programme in Delhi. International Indexed \& Refereed Research Journal, IV, 47-48

Ellsworth, J. B. (2000). Surviving Change: A Survey of Educational Change Models: ERIC.

Ely, D. P. (1976). Creating the conditions for change. In Bond and FabisofREds.), changing times: changing libraries, (pp. 150-162). Champagne, Illinois: Graduate School of Library Science.

Ely, D. P. (1999). Conditions that facilitate the implementation of educational technology innovations. Journal of Research on Computing in Education, 23, (2), 298-315.

Ely, D. P. (1990a). Conditions that facilitate the implementation of educational technology innovations. Journal of Research on Computing in Education, 23, (2), 298-315.

Ely, D. P. (1990b). The Diffusion and Implementation of Educational Technology in Developing Nations: CrossCultural Comparisons of Indonesia, Chile and Peru.

Ertmer, P. A., \& Ottenbreit-Leftwich, A. T. (2010). Teacher technology change: How knowledge, confidence, beliefs, and culture intersect. Journal of research on Technology in Education, 42(3), 255-284.

Ertmer, P. A., Ottenbreit-Leftwich, A., \& York, C. S. (2006). Exemplary technology-using teachers: Perceptions of factors influencing success. Journal of Computing in Teacher Education, 23(2), 55-61.

Espino, M. G. T. (2012). Factors that Influence Implementation of Information and Communication Technology for English as a Foreign Language in a Mexican Educational Context: Case Study. 2(1), 27-48.

Fabry, D. \& Higgs, J.(1997), 'Barriers to the effective use of technology in education', Journal of Educational Computing, 17(4), pp. 385-395.

Gill, L., \& Dalgarno, B. (2008). Influences on pre-service teachers' preparedness to use ICTs in the classroom. Hello! Where are you in the landscape of educational technology? Proceedings oscillate Melbourne 2008.

Goktas, Y., Yildirim, S., \& Yildirim, Z. (2009). Main barriers and possible enablers of ICTs integration into pre-service teacher education programs. Educational Technology \&Society, 12(1), 193-204.

Gülbahar, Y. (2008). ICT usage in higher education: a case study on pre-service teachers and instructors The Turkish Online Journal of Educational Technology, 7(1), 32-37.

Haber, J., \& Mills, M. (2008). Perceptions of barriers concerning effective online teaching and policies: Florida community college faculty. Community College Journal of Research and Practice, 32(4-6), 266-283.

Henning, J. E., Robinson, V. L., Herring, M. C., \& McDonald, T. (2006). Integrating technology during student teaching: An examination of teacher work samples. Journal of Computing in Teacher Education, 23(2), 71-76.

Hong, K.-S., \& Songan, P. (2011). ICT in the changing landscape of higher education in Southeast Asia. Australasian Journal of Educational Technology, 27(8), 1276-1290.

Hutchison, A. C. (2009). A national survey of teachers on their perceptions, challenges, and uses of information and communication technology. Doctoral Dissertation, ProQuest, Clemson University.

Larner, D. \& Timberlake, L.(1995), 'Teachers with limited computer knowledge: variables affecting use and hints to increase use', The Curry School of Education, University of Virginia.

Liu, S.-H. (2012). A Multivariate Model of Factors Influencing Technology Use by Pre-service Teachers during Practice Teaching. Educational Technology \& Society, 15(4), 137-149.

Luan, W. S., \& Teo, T. (2009). Investigating the technology acceptance among student teachers in Malaysia: An application of the technology acceptance model (TAM) The Asia-Pacific Education Researcher, 18(2), 261-272.

Mehlinger, H. D., \& Powers, S. M. (2002). Technology and teacher education: A Guide for policy makers. Boston: Houghton Mifflin Company.

Moursund, D., \& Bielefeldt, T. (1999). Will new teachers be prepared to teach in the digital age: A national survey on information technology in teacher education? Santa Monica, CA: Milken Family Foundation Publications. Exchange on Information Technology.

Mutohar, A. (2012). Identifying and bridging the gaps of ICT integration in primary and secondary education in Indonesia. Dissertation Master of Arts, University of Texas at Austin.

Nawawi, H., Dato, Mokhtar, B, (2005). Conditions facilitating utilization of instructional technology in higher education: A study of University Putra Malaysia, Malaysia. Doctoral Dissertation.

Obiri-Yeboah, K., Kwarteng, K. O., \& Kyere-Djan, R. (2013). Factors Affecting ICT Adoption in Tertiary Institutions in Ghana: A Case of Kwame Nkrumah University of Science and Technology. Paper presented at the Information and Knowledge Management. 
Ottesen, E. (2006). Learning to teach with technology: authoring practiced identities. Technology, Pedagogy and Education. 15(3), 275-290.

Pope, M., Hare, D., \& Howard, E. (2002). Technology integration: Closing the gap between what pre-service teachers are taught to do and what they can do. Journal of Technology and Teacher Education, 10(2), 191-203.

Pope, M., Hare, D., \& Howard, E. (2005). Enhancing technology use in student teaching: A case study. Journal of Technology and Teacher Education, 13(4), 573-618.

Qablan, A. M., Abuloum, A., \& Al-Ruz, J. A. (2009). Effective integration of ICT in Jordanian schools: An analysis of pedagogical and contextual impediments in the science classroom. Journal of Science Education and Technology, 18(3), 291-300.

Rogers Everett, M. (2003). Diffusion of innovations A Division of Macmillan Publishing Co.,Inc. Fifth Edition: Printed in the United States of America.

Russell, G. \& Bradley, G. (1997), 'Teachers 'computer anxiety: implications for professional development', Education and Information Technologies, 2(1), pp. 17-30

Slaouti, D., \& Barton, A. (2007). Opportunities for practice and development: Newly qualified teachers and the use of information and communications technologies in teaching foreign languages. Journal of In-Service Education, 33(4), 405-424.

Snoeyink, R., \& Ertmer, P. (2001). Thrust into technology: How veteran teachers respond. Journal of Educational Technology Systems, 30, 85-111

Surry, D., \& Ely, D. (2002). Adoption, diffusion, implementation, and institutionalization of instructional design and technology. Trends and issues in instructional design and technology, Upper Saddle River, NJ: Pearson Education.

Swain, C. (2006). Pre-service teachers' self-assessment using technology: Determining what is worthwhile and looking for changes in daily teaching and learning practices. Journal of Technology and Teacher Education, 14(1), 29-59.

Teo, T. (2009). Examining the Relationship between Student Teachers' Self-Efficacy Beliefs and Their Intended Uses of Technology for Teaching: A Structural Equation Modelling Approach. Turkish Online Journal of Educational Technology-TOJET, 8(4), 7-15.

Türkmen, H., Pedersen, J. E., \& McCarty, R. (2007). Exploring Turkish Pre-service Science Education Teachers' Understanding of Educational Technology and Use. Faculty Publications: Department of Teaching, Learning and Teacher Education, 87.

Whetstone, L. \& Carr-Chellman, A. (2001), 'preparing pre-service teachers to use technology: survey results', TechTrends, 45(4), pp. 11-17.

Willis, E. M., \& de Montes, L. S. (2002). Does requiring a technology course in pre-service teacher education affect student teacher's technology use in the classroom? Journal of Computing in Teacher Education, 18(3), 76-80.

Woldab, Z. E. (2014). E-Learning Technology in Pre-Service Teachers Training-Lessons for Ethiopia. Journal of Educational and Social Research, 4(1), 159.

Yuen Fook, C., Sidhu, G. K., Kamar, N., \& Abdul Aziz, N. (2011). Pre-Service Teachers' Training in Information Communication and Technology for the ESL Classrooms in Malaysia. Turkish Online Journal of Distance Education, 11(3), 97-108. 